\title{
ANGIOGRAPHIC EVIDENCE OF SMALL VESSEL INVOLVEMENT IN FABRY DISEASE
}

\author{
Ferid XASIYEV*, Umur TÜRKYILMAZ*, Anıl ARAT**, Mehmet Akif TOPÇUOĞLU*, Ethem Murat ARSAVA* \\ * Hacettepe University Faculty of Medicine, Department of Neurology, Ankara, TURKEY \\ * *Hacettepe University Faculty of Medicine, Department of Radiology, Ankara, TURKEY
}

\begin{abstract}
Cerebral deep penetrating/medullary subcortical small vessel involvement is the major form of neurovascular disease observed in Fabry's disease. Dilatative cerebral arteriopathy, mostly in vertebrobasilar circulation, is the most common and recognized angiographic finding of Fabry disease. We herein present angiographically-documented cerebral diffuse (left>right) "distal arteriopathy" in a case of Fabry disease. Awareness of possible occurrence of this type of neurovascular involvement in the Fabry disease spectrum is of value not only in terms of preventing false diagnoses such a primary cerebral vasculitic disorders, but also establishing the right specific treatment such as enzyme replacement in a timely fashion.

Keywords: Fabry disease, arteriopathy, vasculitis, lacune, small vessel disease.
\end{abstract}

\section{FABRY HASTALIĞINDA SEREBRAL KÜÇÜK DAMAR HASTALIĞI: ANJİOGRAFIK DÖKÜMENTASYON}

\section{ÖZET}

Fabry hastalığında genel olarak serebral derin penetran/medüller küçük damar tutulumu izlenir. Daha çok vertebrobaziler dolaşımda olan dilatatif arteriopati en sık ve iyi bilinen anjiografi bulgusudur. Burada, anjiografi ile dökümente edilmiş serebral yaygın (sol>sağ) "distal arteriopati" saptanan bir Fabry olgusu sunulmaktadır. Bu tarz tutulumun Fabry hastalığı spektrumunda olduğunun bilinmesi yanlış tanı ve tedaviyi engelleme potansiyeli açısından değerlidir.

Anahtar Sözcükler: Fabry hastalığı, arteriopati, vaskulit, lakün, küçük damar hastalığı.

\section{INTRODUCTION}

Fabry disease is an X-linked lysosomal storage disorder caused by the deficient activity of the enzyme $\alpha$-galactosidase A (1). Among its many presentations cerebrovascular diseases constitute a significant proportion. Nonetheless the diagnosis might be challenging especially in the setting of atypical clinical presentations. Herein we highlight angiographic features in a patient with Fabry disease, which might alert clinicians regarding the possibility of such a diagnosis.
CASE

A 22-year-old male was admitted to our center because of recurrent episodes of double vision. His past medical history was unremarkable except for several syncopal episodes that have occurred four years prior to admission. He first complained of double vision one year after these syncopal episodes; no formal diagnosis was established at that time and his complaints subsided within a period of few months. A cranial magnetic resonance imaging (MRI) study was

Corresponding author: Ethem Murat Arsava MD. Prof. Hacettepe University Faculty of Medicine, Department of Neurology, 06100 Sihhiye, Ankara, Turkey. Phone: +903123051806 E-mail: arsavaem@hotmail.com

Received: 19.06 .2018 Accepted: 05.07 .2018

This article should be cited as following: Xasiyev F, Türkyılmaz U, Arat A, Topçuoğlu M.A, Arsava M.E. Angiographic evidence of small vessel involvement in Fabry disease. Turkish Journal of Cerebrovascular Diseases 2018; 24 (3): 124-127. doi:10.5505/tbdhd.2018.64326 


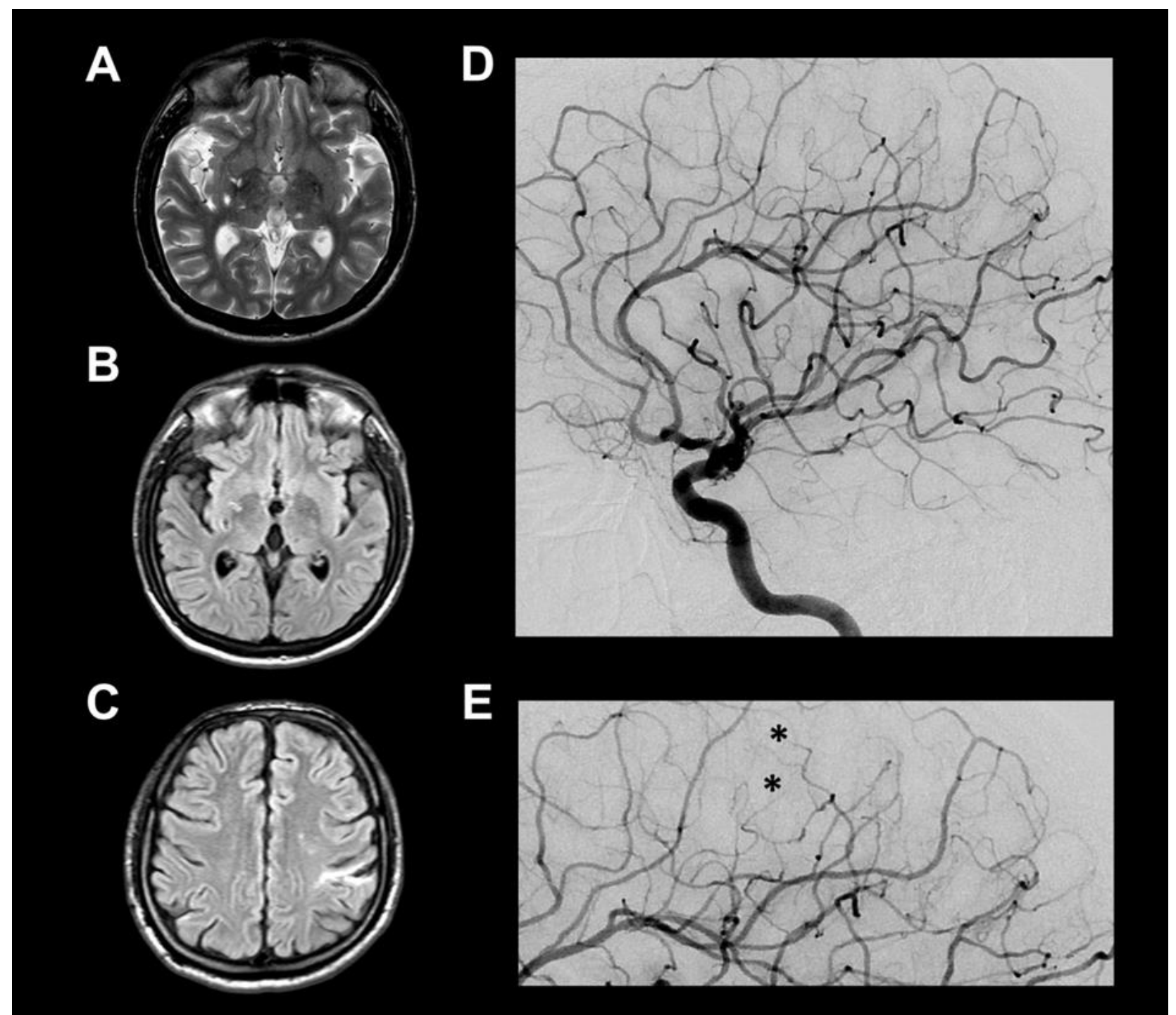

Figure. T2- (A) and fluid attenuated inversion recovery (B, C) sequences of the brain showing multiple lacunar infarcts and a left parietal cortical infarct. Conventional angiography obtained by left internal carotid injection shows numerous stenotic and irregular arteries with sharp cutoffs in the distal middle cerebral artery branches (D; magnified view is shown in E with cut-offs noted by asterisk').

performed three years later when he had a recurrent episode of double vision and revealed the presence of multiple chronic infarcts, which had led to the referral of the patient to our institution for further investigations.

The neurological examination of the patient showed right-sided gaze evoked nystagmus, subtle sixth nerve palsy on the left side, increased deep tendon reflexes and positive Babinski sign on the left side. The basic blood work-up including complete blood count, electrolytes, liver and renal function tests were within normal limits. MRI showed multiple, subacute and chronic lacunar lesions distributed in the brain stem, basal ganglia and subcortical white matter; an additional chronic infarct involving the left parietal cortex was also noted (Figure A-C). Cerebral angiography demonstrated irregular stenotic arteries and occlusions with sharp cutoffs especially prominent in the distal branches of the left middle cerebral artery (Figure D-E).

An extensive etiologic evaluation regarding stroke etiology, including fasting lipid levels, levels of coagulation factors, serologic studies for vasculitides and infections, transthoracic and transesophageal echocardiography, 24-hour 
Holter monitoring and lumbar puncture did not show any significant abnormalities.

The patient was diagnosed with Fabry disease only after alpha galactosidase analysis showed decreased level of the enzyme - 2 $\mathrm{nmol} / \mathrm{sec} / \mathrm{mg}$ (normal range $11-40 \mathrm{~nm} / \mathrm{sec} / \mathrm{mg}$ ). Genome analyses revealed the presence of G680A [p.(Arg227Gln)] mutation in the GLA gene. No family history was obtained. Other systemic manifestations of the disease were excluded by dermatologic and ophthalmologic examinations, together with 24-hour urine examination. The patient was discharged following initiation of enzyme replacement therapy.

\section{DISCUSSION}

The clinical manifestations of Fabry disease include neurologic (acroparesthesias, neuropathic pain, hypohidrosis, cerebrovacular disease), ocular (corneal inclusions, cataracts), dermatologic (cutaneous angiokeratoma), renal or cardiac symptoms, and are considered to occur due to progressive accumulation of globotriaosylceramide and related glycosphingolipids within the vascular endothelium, kidney, myocardium and dorsal root ganglia (1). Although involvement of the cerebral circulation is generally preceded by dermatologic, renal or cardiac symptoms, it is not uncommon to encounter patients presenting with stroke as the first manifestation of the disease (2).

Ischemic lesions involving the brainstem were considered as the culprit of diplopia symptoms in our patient. However, as no imaging studies were performed in the acute stage a definitive clinico-radiologic correlation based on diffusion weighted imaging studies could not be established. Although the presence of multiple lacunar infarcts raised the possibility of Fabry disease, the diagnosis was not apparent due to the absence of other suggestive signs like dilatative arteriopathy or T1-hyperintense deep gray matter lesions on imaging studies. Moreover the detection of stenotic and occluded arteries on angiography raised suspicion for other alternative etiologies for the findings in our patient.

The cerebral vasculopathy observed in Fabry disease patients can involve both the large and small sized vessels of the cerebral circulation (3). Large vessel pathologies are easily detected on angiographic investigations and include features like elongation, dilatation and dolichoectasia of affected vessels $(4,5)$. Atherosclerotic changes can also be noted. All of these large vessel pathologies primarily involve vertebral and basilar arteries, however vessels of the anterior circulation can also be affected. On the other hand, direct demonstration of small vessel pathology, considered to be secondary to occlusion of arterioles due to glycosphingolipid deposition or endothelial function, is more challenging. The detection of symptomatic or clinically silent lacunar infarcts together with T2 hyperintense lesions in subcortical white matter, centrum semiovale, basal ganglia and brainstem are considered as evidence of small vessel disease in Fabry disease patients $(4,6-8)$. Nonetheless, it is well known from pathologic studies that small vessel involvement is not limited to deep penetrating arteries in Fabry disease and extends to medium to small sized arterioles and capillaries in almost every location of cerebral circulation (9). Therefore the angiographic findings in our patient fit very well these observations in the literature and can be considered as direct imaging evidence of small to medium sized arteriolar involvement in the setting of Fabry disease.

Fabry disease should always be suspected in young male patients with recurrent strokes, especially in the presence of suggestive family history and neuroimaging features. This report underscores the importance of angiographic studies in pinpointing the vascular pathology in such patients.

\section{REFERENCES}

1. Brady RO, Gal AE, Bradley RM, Martensson E, Warshaw AL, Laster L. Enzymatic defect in Fabry's disease. Ceramidetrihexosidase deficiency. N Engl J Med. 1967 May 25;276(21):1163-7.

2. Sims K, Politei J, Banikazemi M, Lee P. Stroke in Fabry disease frequently occurs before diagnosis and in the absence of other clinical events: natural history data from the Fabry Registry. Stroke. 2009;40(3):788-94.

3. Moore DF, Kaneski CR, Askari H, Schiffmann R. The cerebral vasculopathy of Fabry Disease. J Neurol Sci 2007;257:25863.

4. Mitsias P, Levine S. Cerebrovascular complications of Fabry disease. Ann Neurol 1996;40:8-17.

5. Fellgiebel A, Keller I, Marin D, Müller MJ, Schermuly I, Yakushev I, Albrecht J, Bellhäuser H, Kinateder M, Beck M, Stoeter P. Neurology. 2009;72(1):63-8.

6. Crutchfield KE, Patronas NJ, Dambrosia JM, Frei KP, Banerjee TK, Barton NW, Schiffmann R. Quantitative analysis of cerebral vasculopathy in patients with Fabry disease. Neurology 1998;50:1746-49. 
Xasiyev et al.

7. Lidove 0 , Klein I, Lelièvre JD, Lavallée P, Serfaty JM, Dupuis E, Papo T, Laissy JP. Imaging Features of Fabry disease. AJR 2006;186:1184-91.

8. Buechner S, Moretti M, Burlina AP, Cei G, Manara R, Ricci R, Mignani R, Parini R, Di Vito R, Giordano GP, Simonelli P, Siciliano G, Borsini W. Central nervous system involvement in Anderson Fabry disease: a clinical and MRI retrospective study. J Neurol Neurosurg Psychiatry 2008;79:1249-1254.

9. Tagliavini F, Pietrini V, Gemignani F, Lechi A, Pallini R, Federico A. Anderson-Fabry's disease: neuropathological and neurochemical investigation. Acta Neuropathol. 1982;56(2):93-8. 